\title{
The Effects of Higher Education's Institutional Organizational Climate on Performance Satisfaction: Perceptions of University Faculty in Taiwan
}

\author{
Cheng-Cheng Yang ${ }^{1}$ \\ ${ }^{1}$ Graduate Institute of Educational Administration and Policy Development, National Chiayi University, Taiwan \\ Correspondence: Cheng-Cheng Yang, National Chiayi University, Taiwan. E-mail: yccjason@mail.ncyu.edu.tw
}

Received: June 6, 2015

Accepted: July 3, 2015

Online Published: July 25, 2015

doi:10.5539/ibr.v8n8p103

URL: http://dx.doi.org/10.5539/ibr.v8n8p103

\begin{abstract}
The performance of higher education institutions in the world has become an emergent issue. Asian countries tried to offer more autonomy to universities; consequently, universities moved toward scientific management and emphasized organizational performance and efficiency. Taiwan is no exception to this trend. Thus, studying the institutional organizational climate in higher education is critical for current higher education changes in Taiwan, and it is even more important to study organizational climate's effects on universities. This research developed a questionnaire to explore Taiwanese university faculty members' perceived institutional organizational climate and their satisfaction with teaching and research in the last five years. The findings of this research implicate that gender difference is an important factor to consider when university administration wants to enhance the internal organizational climate in Taiwan. Years of employment, university history, and research field all have different effects on faculty members' perceived organizational climate aspects. Implications for policy making and future researches are discussed in this research article.
\end{abstract}

Keywords: institutional organizational climate, performance satisfaction, university faculty, Taiwan

\section{Introduction}

The performance of higher education institutions in the world has become an emergent issue. The world's university rankings pushed governments to emphasize their universities' outcomes and rankings (Marginson, 2006). Governments in the world link the performance of their local higher education institutions with world reputation and rankings and believe this reputation and ranking can help enhance national competitiveness by cultivating local talents and attracting international faculty and students. The idea of linking university performance and national competiveness has significantly influenced recent higher education reform and policy making. Nation-states in the Asia Pacific region are no exception to this trend (Deem, Mok, \& Lucas, 2008; Shin \& Harman, 2009).

Marginson (2006) further explained this phenomenon by distinguishing among competition between universities in terms of national and global spheres. At the local/national level, universities compete with each other for stronger students and research grants from local institutes or agencies. At the global level of higher education competition, a university's performance is measured by research outcomes (Marginson, 2006).

Marginson's (2006) paper reminds us that competition among universities can occur differently at national and international levels. In this context, research publication numbers are seen as one key indicator for both international and local higher education competition spheres. However, every higher education system differentiates it institutions into various types in some way. University type and differences in resources influence their capacities to compete in terms of research performance. Therefore, it is important to consider a university's resources and types when conducting higher education research and to explore the causal factors influencing different types of university research to identify the hidden inequalities and challenges of higher education institutions.

Another important point to consider in this discussion is the importance of university performance. Governments care about the output of higher education institutions, but rarely think of ways to enhance university performance; researchers generally agree that university performance significantly depends on faculty members' research and teaching. In fact, the literature on educational administration has highlighted the importance of the organizational 
climate and its effects on teachers' behavior (Litwin \& Stringer, 1966). Relatively fewer studies explore this issue at the higher education level.

The contextual background of this research is the higher education system in Taiwan. Higher education in Taiwan has entered the phase of mass higher education conceptualized by Trow (1972). The 159 higher education institutions in Taiwan included 124 universities, 21 colleges, and 14 junior colleges in 2014 (Ministry of Education in Taiwan, 2015). Certain characteristics of higher education institutions will be included in the study design of this research to highlight distinctions between universities. These characteristics include private and national institutions, technology-focused institutions, and academic-focused institutions. During the last decade, Taiwan's government has sought to strengthen its higher education and, thus, implemented several special policies. A number of universities were selected by the Taiwanese government as research-focused universities and teaching-focused universities; therefore, this research recognizes these variables as important characteristics to consider in the research design.

The purposes of this research include the following:

1) To conceptualize the theoretical components of the organizational climate in higher education;

2) To develop a higher education organizational climate questionnaire;

3) To administer this questionnaire to 300 university faculty in Taiwan;

4) To analyze university faculty members' perceptions of the higher education organizational climate in Taiwan;

5) To explore the effects of higher education's organizational climate on faculty members' perceived satisfaction with research and teaching performance.

\section{Literature Review}

\subsection{Organizational Climate in Higher Education}

Studies of organizational behavior originate from the management field, which explores interactions between humans and the environment. For example, Owens and Valesky (2014) argued that organizational behavior originates from interactions between individual and environmental factors in the organization and can be represented by one formula: $\mathrm{b}=\mathrm{f}\left(\mathrm{p}^{*} \mathrm{e}\right)$. In this formula, $b$ refers to human behavior, $p$ refers to people in the organization, and $e$ refers to environmental factors. In the context of higher education institutions, $p$ can be used to refer to faculty, staff, students, and administrators; $e$ to campus facilities, university regulations, teaching quality, library quality, atmosphere, building design, etc.; and $b$ to performance or any behavioral perceptions of participants at universities.

Organizational climate is an important theoretical construct because it can help recognize the wellness of an organization and distinguish among types of organizations (Moran \& Volkwein, 1988). To measure organizational climate in one organization, investigators have to measure organization members' perceptions. In fact, studying organizational climate is highly valuable because it significantly relates to important outcome variables (Field \& Abelson, 1982). In many studies, it has been proved to positively relate to good behavior and high motivation (Litwin \& Stringer, 1966).

However, in the field of higher education, researchers have pointed out that organizational culture and climate are two similar, but distinctive concepts. Peterson, Cameron, Jones, Mets, and Ettington (1986) asserted that organizational culture and organizational climate are difficult to differentiate and refer to the entire combination of experiences in higher education institutions. This research defines organizational climate in higher education from the perspectives of management theories, where organizational culture refers to an organization's behavioral regulations, hypotheses, and beliefs. The organizational climate can be defined as organizational members' perceptions of regulations, hypotheses, and beliefs within the organization. Organizational culture includes cultural characteristics that are difficult to capture whereas organization climate is a set of psychological constructs to capture these cultural characteristics. Researchers argue that organizational climate not only conceptualizes cultures, but also measures the characteristics of the total environment in the school (Owens \& Valesky, 2014).

Peterson et al. (1986) asserted that organizational climate in higher education is how faculty, administrators, and students perceive environmental factors of the university or college. Astin (1968) pointed out that organizational climate can be captured from students' perspectives on university's characteristics, such as school policies, curriculum, facility, teaching content, interactions with colleagues, and other collegiate experiences. Educational Testing Service (1973) developed an Institutional Goals Inventory to measure university members' views on 
their institutions' organizational goals.

This research developed a questionnaire to measure university faculty's perceptions on the higher education organizational climate based on the literature reviewed herein. The aspects of the higher education organizational climate defined in this questionnaire include research resources, teaching resources, research cooperation, organizational justice, internationalization, and learning innovation.

\subsection{Effects of Organizational Climate on University Faculty Performance: The Macro Perspective and Background Variable Differences}

Neumann (1978) administered questionnaires to 57 departments and research institute professors in the northeastern region of the United States. This result indicated that organizational climate relates to professors' job satisfaction, but this relationship differs among the different factors within the organizational climate. The organizational goal attribute has a lower relationship with job satisfaction, while professors' perceptions of personal autonomy would have a higher correlation with their job satisfaction; this relationship is even more significant when these professors' research field is social science. Neumann's research holds its explanation power because most of its samples were professors at research-oriented universities; if these professors were working at teaching-oriented or community colleges, then the research results could be different. This research also highlighted the importance of considering higher education institutions' orientation and organizational mission in the research design.

Peterson and White (1992) administered the organizational climate for teaching and learning questionnaires to faculty members and administrators in three community colleges, three private liberal arts colleges, and four comprehensive universities. They analyzed and compared professors' and administrators' perceptions on institutional organizational culture and its impact on their work motivation. The research found that professors and administrators have very different views of a university's mission and organizational culture. Administrators viewed economic and financial feedback as an important organizational goal. This research also found that different institutions will reflect a different organizational climate and the gap between professors and administrators will differ according to different institutions.

These two studies focused on institutional differences; however, there other studies have focused on gender and social economic status differences. Bronstein and Farnsworth (1998) compared university professors' perceptions on departmental organizational climate, focusing on gender. This research was based on gender inequality theory and used one research-oriented university as the sample. Most professors at this university felt a positive organizational environment, and female professors perceived different treatment and higher feelings of threat than male faculty. Female professors also perceived inequality in their hiring and promotion process.

\section{Research Method}

The research design, definition of terms, and samples will be described in this section.

\subsection{Research Design}

The author of this research developed a questionnaire that includes three main sections to explore Taiwanese university faculty members' perceived organizational climate and their self-evaluated performance satisfaction. The questionnaire includes three sections: background variables, organizational climate aspects, and performance satisfaction. This research aimed to determine how current Taiwanese university faculty members view their university's research resources, teaching resources, research collaboration, organizational justice, internationalization, and learning innovation as well as their satisfaction with their teaching and research performance. The background variables in the questionnaire helped determine the respondent samples' background information, and the author applied $t$-test and ANOVA to examine the differences of organizational climate and performance satisfaction perceptions based on the background variables. Figure 1 depicts the conceptual diagram of the research design. 


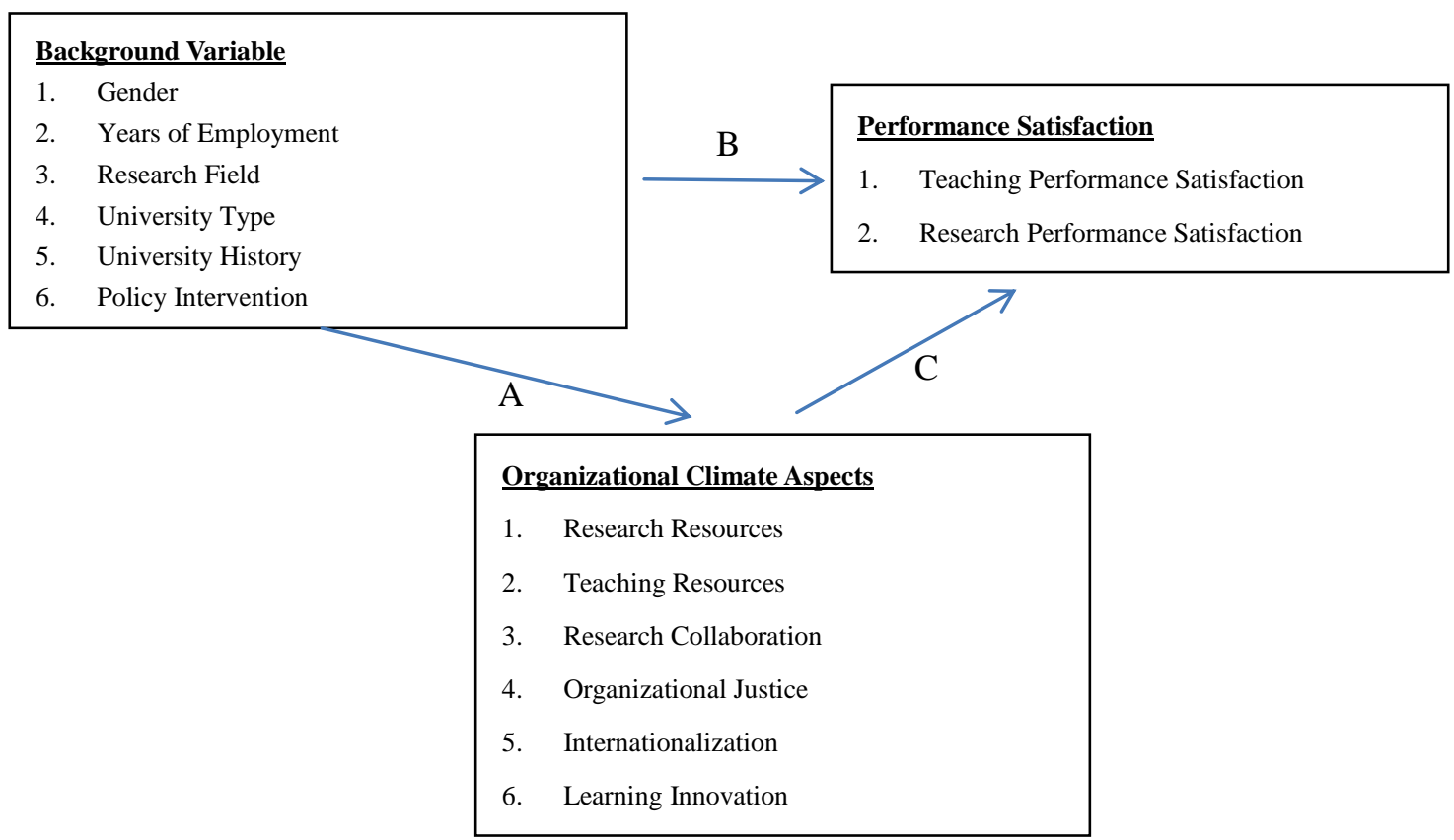

Figure 1. Conceptual framework of research design

Arrow A: Use $t$-test and ANOVA to test the differences of means of organizational climate aspects with different background variables

Arrow B: Use $t$-test and ANOVA to test the differences of means of performance satisfaction aspects with different background variables

Arrow C: Use regression analysis to test the effects of organizational climate aspects on performance satisfaction aspects.

\subsection{Definition of Terms}

\subsubsection{Background Variables}

In this research, background variables are included in the questionnaire based on literature reviews that are seen as potential influential factors of organizational climate aspects and performance satisfaction. These variables include gender, years of employment, research field, university type, university history, and policy intervention. The policy intervention variable was used to ask participants if their university received a teaching excellence fund and research excellence fund from the Taiwanese government. The teaching excellence fund is a policy first implemented by the Taiwanese government in 2005. This competition-based fund project offers awarded universities Ministry of Education (MOE) funds to help pursue teaching excellence. The research excellence fund is similarly a competition-based fund project in which the MOE helps awarded institutions pursue research excellence and international research benchmarks.

\subsubsection{Institutional Organizational Climate}

In this research, the institutional organizational climate, defined as university faculty's perceptions of their university's climate, were demonstrated via six aspects: research resources, teaching resources, research collaboration, organizational justice, internationalization, and learning innovation.

a. Research resources:

This aspect measures how university faculty members perceive their university's positive climate in terms of teachers' application for research funds, the hiring of research assistants, students' participation in teachers' research projects, colleagues' motivation to conduct research, and the university's internal support for scientific research.

b. Teaching resources:

This aspect measures how university faculty members perceive their university's positive climate in terms of the university's emphasis on teaching performance, the hiring of teaching assistants, application of teaching 
excellence funds, teaching activity participation, colleagues' motivation to refine their teaching, and learning activities being held to enhance teaching.

c. Research collaboration:

This aspect measures how university faculty members perceive their university's positive climate in terms of colleagues' cooperative motivation to work on research projects together as well as their willingness to do joint research projects, share research resources with one another, share the experience of research article publication, regularly meet together and discuss research experiences, partake in others' research works, and co-author publishing articles.

d. Organizational justice:

This aspect measures how university faculty members perceive their university's positive climate in terms of teacher salary fairness, promotion system fairness, reward system fairness, resource allocation system fairness, teaching load allocation fairness, and research performance evaluation fairness.

e. Internationalization:

This aspect measures how university faculty members perceive their university's positive climate in terms of the university's encouragement to publish international journal or book articles and participate in international conferences or seminars; the university's efforts to internationalize the administration; admit international students and hire international academic talents, and host international events; and the university's encouragement to teach in foreign languages.

f. Learning innovation:

This aspect measures how university faculty members perceive their university's positive climate in terms of teachers' willingness to learn new knowledge, try innovative teaching, strive for innovative research, use innovative teaching and research methods, and express new knowledge as well as the university's effort to creating new service modes and reward innovative actions.

The questionnaire applied a Likert scale to measure faculty members' perceived institutional organizational climate. When answering each item of the institutional organizational climate section, participants rated the item from 1 (strongly disagree) to 5 (strongly agree) based on their own experiences. A higher average score meant they had a more positive feeling about the item's description.

\subsubsection{Performance Satisfaction}

The performance satisfaction variable in this research is listed in the questionnaire to ask about participants' satisfaction with their teaching and research performance at the university during the preceding five years. The questionnaire applied a Likert scale to measure faculty members' perceived performance satisfaction. They rated each item from 1 (strongly disagree) to 5 (strongly agree) based on their own experiences. A higher average score meant they had a higher level of satisfaction with the item's description.

\subsection{Samples}

This research administered approximately 600 questionnaires to university faculty members distributing equally among national and private universities in Taiwan. In Taiwan, every city or county has at least one national and one private university; therefore, this research administered questionnaires to university faculty members employed at one national and one private university of each city or county. At each university, we administered five questionnaires to professors and five questionnaires to associate and assistant professors in different colleges or schools. Thus, the samples could reflect different research fields and different regions. Table 1 provides a frequency analysis of background variables of returned questionnaires. The total number of valid returned samples was 297. As this table demonstrates, the percentage of different background variables is equivalently distributed. The only problem is that fewer than 10 valid samples were returned from the national university of technology and private university of technology; thus, these questionnaires were not included in the ANOVA analysis when we examined the perception differences between university types. 
Table 1. Frequency analysis of returned questionnaires

\begin{tabular}{|c|c|c|c|}
\hline \multicolumn{4}{|l|}{ Total Number of Returned Valid Samples: 297} \\
\hline \multicolumn{4}{|l|}{ Background Variables } \\
\hline Items & Group & Number & Percentage \\
\hline \multirow[t]{2}{*}{ Gender } & Male & 197 & $66.3 \%$ \\
\hline & Female & 100 & $33.7 \%$ \\
\hline \multirow[t]{4}{*}{ Years employed at university } & Less than 5 years & 112 & $37.7 \%$ \\
\hline & 6 to 10 years & 57 & $19.2 \%$ \\
\hline & 11 to 15 years & 42 & $14.1 \%$ \\
\hline & Over 16 years & 86 & $29.0 \%$ \\
\hline \multirow[t]{5}{*}{ Research field } & Humanities \& Arts & 50 & $16.8 \%$ \\
\hline & Social Science and Management & 91 & $30.6 \%$ \\
\hline & Education & 36 & $12.1 \%$ \\
\hline & Natural and Life Science & 70 & $23.6 \%$ \\
\hline & Engineering & 50 & $16.8 \%$ \\
\hline \multirow[t]{4}{*}{ University types } & National University & 192 & $64.6 \%$ \\
\hline & National University of Technology & 8 & $2.7 \%$ \\
\hline & Private University & 96 & $32.3 \%$ \\
\hline & Private University of Technology & 1 & $0.3 \%$ \\
\hline \multirow[t]{4}{*}{ University history } & Less than 15 years & 101 & $34 \%$ \\
\hline & 16 to 25 years & 61 & $20.5 \%$ \\
\hline & 26 to 35 years & 25 & $8.4 \%$ \\
\hline & Over 36 years & 110 & $37 \%$ \\
\hline \multirow{2}{*}{$\begin{array}{l}\text { If serving university is awarded Building Teaching Excellence at } \\
\text { University Fund from Ministry of Education in Taiwan }\end{array}$} & Yes & 227 & $76.4 \%$ \\
\hline & No & 70 & $23.6 \%$ \\
\hline \multirow{2}{*}{$\begin{array}{l}\text { If serving university is awarded Building World-Class University Fund } \\
\text { from Ministry of Education in Taiwan }\end{array}$} & Yes & 123 & $41.1 \%$ \\
\hline & No & 174 & $58.6 \%$ \\
\hline
\end{tabular}

\section{Research Findings}

Table 2 summarizes the results of the descriptive analysis of faculty members' perceived aspects of the institutional organizational climate. Faculty members perceived a higher level of research resources and internationalization but relatively lower levels of research collaboration and organizational justice, although they generally felt positively about the institutional organizational climate at Taiwanese universities.

Table 2. Mean and SD of faculty members' perceived institutional organizational climate in different aspects

\begin{tabular}{lll}
\hline Aspects & Mean & SD \\
\hline Research Resources & 4.0645 & 0.63831 \\
Teaching Resources & 3.7929 & 0.75016 \\
Research Collaboration & 3.4127 & 0.87982 \\
Organizational Justice & 3.4161 & 0.86562 \\
Internationalization & 4.0114 & 0.70368 \\
Learning Innovation & 3.7653 & 0.72255 \\
\hline
\end{tabular}


Table 3 summarizes the results of the descriptive analysis of faculty members' perceived aspects of teaching and research performance satisfaction. Faculty members indicated higher satisfaction with their teaching performance, but relatively lower satisfaction with their research performance, although they generally felt satisfied with their teaching and research performance from the last five years.

Table 3. University faculty members' perceived teaching and research performance satisfaction

\begin{tabular}{llc}
\hline Items & Mean & SD \\
\hline 1. My satisfaction with my teaching performance in the last five years & 4.037 & 0.6330 \\
2. My satisfaction with my research performance in the last five years & 3.586 & 0.9117 \\
\hline
\end{tabular}

Table 4 summarizes the results of the $t$-test analysis of faculty members' perceived institutional organizational climate based on gender. Male faculty members perceived significantly higher climate aspects of research resources, research collaboration, organizational justice, satisfaction with teaching, and satisfaction with research. No significant gender difference was evident for teaching resources, internationalization, or learning innovation.

Table 4. T-test results of institutional organizational climate perceived by faculty members based on gender

\begin{tabular}{|c|c|c|c|c|c|c|}
\hline Aspect & Gender & $\mathrm{N}$ & Mean & $\mathrm{SD}$ & $\mathrm{T}$ & $P$ \\
\hline \multirow[t]{2}{*}{ Research Resources } & Male & 197 & 4.1276 & .58997 & 2.272 & $.024 *$ \\
\hline & Female & 100 & 3.9400 & .71101 & & \\
\hline \multirow[t]{2}{*}{ Teaching Resources } & Male & 197 & 3.8519 & .67946 & 1.769 & .079 \\
\hline & Female & 100 & 3.6767 & .86483 & & \\
\hline \multirow[t]{2}{*}{ Research Collaboration } & Male & 197 & 3.5649 & .82940 & 4.307 & $.000 * * *$ \\
\hline & Female & 100 & 3.1129 & .90312 & & \\
\hline \multirow[t]{2}{*}{ Organizational Justice } & Male & 197 & 3.5439 & .83740 & 3.645 & $.000 * * *$ \\
\hline & Female & 100 & 3.1643 & .86917 & & \\
\hline \multirow[t]{2}{*}{ Internationalization } & Male & 197 & 4.0444 & .66078 & 1.077 & .283 \\
\hline & Female & 100 & 3.9463 & .78078 & & \\
\hline \multirow[t]{2}{*}{ Learning Innovation } & Male & 197 & 3.8223 & .69958 & 1.919 & .056 \\
\hline & Female & 100 & 3.6529 & .75682 & & \\
\hline \multirow[t]{2}{*}{ Satisfaction with Teaching } & Male & 197 & 4.096 & .6110 & 2.286 & $.023^{*}$ \\
\hline & Female & 100 & 3.920 & .6618 & & \\
\hline \multirow[t]{2}{*}{ Satisfaction with Research } & Male & 197 & 3.751 & .8107 & 4.218 & $.000 * * *$ \\
\hline & Female & 100 & 3.260 & 1.0112 & & \\
\hline
\end{tabular}

Note. $* p<.05 ; * * p<.01 ; * * * p<.001$.

Table 5 summarizes the results of the $t$-test analysis comparing faculty members' perceived institutional organizational climate between faculty at national and private universities. National university faculty members had significantly higher perceptions for teaching resources and research satisfaction. No significant institutional type differences emerged for research resources, research collaboration, organizational justice, internationalization, learning innovation, or teaching satisfaction. 
Table 5. T-test results of institutional organizational climate perceived by faculty members from different institutional types: national versus private universities

\begin{tabular}{|c|c|c|c|c|c|c|}
\hline Aspect & Institutional Type & $\mathrm{N}$ & Mean & SD & $\mathrm{T}$ & $\mathrm{P}$ \\
\hline \multirow[t]{2}{*}{ Research Resources } & National University & 192 & 4.0766 & .66764 & .732 & .465 \\
\hline & Private University & 96 & 4.0179 & .58783 & & \\
\hline \multirow[t]{2}{*}{ Teaching Resources } & National University & 192 & 3.6693 & .76013 & -3.943 & $.000^{* * *}$ \\
\hline & Private University & 96 & 4.0295 & .66842 & & \\
\hline \multirow[t]{2}{*}{ Research Collaboration } & National University & 192 & 3.4397 & .92938 & .873 & .384 \\
\hline & Private University & 96 & 3.3438 & .77045 & & \\
\hline \multirow[t]{2}{*}{ Organizational Justice } & National University & 192 & 3.3765 & .88441 & -1.049 & .295 \\
\hline & Private University & 96 & 3.4896 & .81704 & & \\
\hline \multirow[t]{2}{*}{ Internationalization } & National University & 192 & 4.0260 & .71159 & .574 & .566 \\
\hline & Private University & 96 & 3.9753 & 69859 & & \\
\hline \multirow[t]{2}{*}{ Learning Innovation } & National University & 192 & 3.7344 & .76123 & -1.161 & .247 \\
\hline & Private University & 96 & 3.8333 & .63809 & & \\
\hline \multirow[t]{2}{*}{ Satisfaction with Teaching } & National University & 192 & 4.052 & .6286 & .522 & .602 \\
\hline & Private University & 96 & 4.010 & .6569 & & \\
\hline \multirow[t]{2}{*}{ Satisfaction with Research } & National University & 192 & 3.656 & .8540 & 2.395 & $.017^{*}$ \\
\hline & Private University & 96 & 3.385 & .9986 & & \\
\hline
\end{tabular}

Note. ${ }^{*} p<.05 ; * * p<.01 ; * * * p<.001$.

Table 6 summarizes the results of the ANOVA analysis comparing faculty members' perceptions of the institutional organizational climate based on years of employment at the university. The $\mathrm{F}$ values show significant mean differences for research resources, organizational justice, internationalization, learning innovation, and research satisfaction. The author conducted a post-hoc comparison between groups, which found that faculty members employed fewer than 5 years perceived significantly higher research resources than those employed 6 to 10 years. Faculty members employed for more than 16 years also perceived significantly more research resources than those employed 6 to 10 years. Another finding is the difference in perception in terms of research satisfaction: Faculty members employed for more than 16 years perceived significantly higher research satisfaction than those employed fewer than 5 years or for 6 to 10 years.

Table 6. ANOVA results of institutional organizational climate perceived by faculty members based on years of employment at university

\begin{tabular}{|c|c|c|c|c|c|c|}
\hline Aspect & Years of Employment & $\mathrm{N}$ & Mean & SD & $\mathrm{F}$ & Post-Hoc \\
\hline \multirow{4}{*}{$\begin{array}{l}\text { Research } \\
\text { Resources }\end{array}$} & a. Less than 5 years & 112 & 4.1939 & .52475 & \multirow[t]{4}{*}{$6.476^{* * * *}$} & $\mathrm{a}>\mathrm{b}$ \\
\hline & b. 6 to 10 years & 57 & 3.7694 & .80031 & & $\mathrm{~d}>\mathrm{b}$ \\
\hline & c. 11 to 15 years & 42 & 3.9830 & .59882 & & \\
\hline & d. Over 16 years & 86 & 4.1312 & .61326 & & \\
\hline \multirow{4}{*}{$\begin{array}{l}\text { Teaching } \\
\text { Resources }\end{array}$} & a. Less than 5 years & 112 & 3.8199 & .68377 & \multirow[t]{4}{*}{2.282} & \\
\hline & b. 6 to 10 years & 57 & 3.5702 & .92900 & & \\
\hline & c. 11 to 15 years & 42 & 3.8175 & .65209 & & \\
\hline & d. Over 16 years & 86 & 3.8934 & .72847 & & \\
\hline \multirow{4}{*}{$\begin{array}{l}\text { Research } \\
\text { Collaboration }\end{array}$} & a. Less than 5 years & 112 & 3.5204 & .85754 & \multirow[t]{4}{*}{2.504} & \\
\hline & b. 6 to 10 years & 57 & 3.1378 & 1.07820 & & \\
\hline & c. 11 to 15 years & 42 & 3.4592 & .77770 & & \\
\hline & d. Over 16 years & 86 & 3.4319 & .78123 & & \\
\hline
\end{tabular}




\begin{tabular}{|c|c|c|c|c|c|c|}
\hline \multirow{4}{*}{$\begin{array}{l}\text { Organizational } \\
\text { Justice }\end{array}$} & a. Less than 5 years & 112 & 3.4936 & .78502 & \multirow[t]{4}{*}{$3.294^{*}$} & \multirow[t]{4}{*}{ n.s. } \\
\hline & b. 6 to 10 years & 57 & 3.1554 & .98394 & & \\
\hline & c. 11 to 15 years & 42 & 3.2687 & .93502 & & \\
\hline & d. Over 16 years & 86 & 3.5598 & .81233 & & \\
\hline \multirow{4}{*}{$\begin{array}{l}\text { International- } \\
\text { ization }\end{array}$} & a. Less than 5 years & 112 & 4.1250 & .60474 & \multirow[t]{4}{*}{$3.426^{*}$} & \multirow[t]{4}{*}{ n.s. } \\
\hline & b. 6 to 10 years & 57 & 3.8136 & .84288 & & \\
\hline & c. 11 to 15 years & 42 & 3.8571 & .68162 & & \\
\hline & d. Over 16 years & 86 & 4.0698 & .70440 & & \\
\hline \multirow{4}{*}{$\begin{array}{l}\text { Learning } \\
\text { Innovation }\end{array}$} & a. Less than 5 years & 112 & 3.8520 & .68066 & \multirow[t]{4}{*}{$3.121 *$} & \multirow[t]{4}{*}{ n.s. } \\
\hline & b. 6 to 10 years & 57 & 3.5363 & .85684 & & \\
\hline & c. 11 to 15 years & 42 & 3.6735 & .77046 & & \\
\hline & d. Over 16 years & 86 & 3.8488 & .62187 & & \\
\hline \multirow{4}{*}{$\begin{array}{l}\text { Satisfaction with } \\
\text { Teaching }\end{array}$} & a. Less than 5 years & 112 & 3.955 & .5597 & \multirow[t]{4}{*}{1.383} & \\
\hline & b. 6 to 10 years & 57 & 4.035 & .7551 & & \\
\hline & c. 11 to 15 years & 42 & 4.048 & .6608 & & \\
\hline & d. Over 16 years & 86 & 4.140 & .6167 & & \\
\hline \multirow{4}{*}{$\begin{array}{l}\text { Satisfaction } \\
\text { Research }\end{array}$} & a. Less than 5 years & 112 & 3.384 & .9515 & \multirow[t]{4}{*}{$7.479 * * *$} & $\mathrm{~d}>\mathrm{a}$ \\
\hline & b. 6 to 10 years & 57 & 3.386 & 1.0980 & & \multirow[t]{3}{*}{$\mathrm{d}>\mathrm{b}$} \\
\hline & c. 11 to 15 years & 42 & 3.690 & .7805 & & \\
\hline & d. Over 16 years & 86 & 3.930 & .6470 & & \\
\hline
\end{tabular}

Note. $* p<.05 ; * * p<.01 ; * * * p<.001$.

Table 7 summarizes the results of the ANOVA analysis comparing faculty members' perceived institutional organizational climate based on their research fields. The F values showed significant mean differences for research resources, teaching resources, research collaboration, and research satisfaction. The author further conducted a post-hoc comparison between groups, finding that faculty members in the humanities and arts fields perceived significantly lower research collaboration than those in education, natural and life science, and engineering. Faculty members in the social sciences and management fields also perceived significantly less research collaboration than those in engineering.

Table 7. ANOVA results of institutional organizational climate perceived by faculty members based on research fields

\begin{tabular}{|c|c|c|c|c|c|c|}
\hline Aspect & Research Field & $\mathrm{N}$ & Mean & SD & $\mathrm{F}$ & Post-Hoc \\
\hline \multirow[t]{5}{*}{ Research Resources } & a.Humanities \& Arts & 50 & 3.9686 & .75222 & $2.654 *$ & n.s. \\
\hline & b.Social Science and Management & 91 & 3.9702 & .63156 & & \\
\hline & c.Education & 36 & 4.2143 & .75477 & & \\
\hline & d.Natural and Life Science & 70 & 4.0327 & .56265 & & \\
\hline & e.Engineering & 50 & 4.2686 & .47305 & & \\
\hline \multirow[t]{5}{*}{ Teaching Resources } & a.Humanities \& Arts & 50 & 3.9233 & .70968 & $2.652 *$ & n.s. \\
\hline & b.Social Science and Management & 91 & 3.6447 & .77428 & & \\
\hline & c.Education & 36 & 3.9722 & .90633 & & \\
\hline & d.Natural and Life Science & 70 & 3.6929 & .69310 & & \\
\hline & e.Engineering & 50 & 3.9433 & .64207 & & \\
\hline
\end{tabular}




\begin{tabular}{|c|c|c|c|c|c|c|}
\hline \multirow{5}{*}{$\begin{array}{l}\text { Research } \\
\text { Collaboration }\end{array}$} & a.Humanities \& Arts & 50 & 2.9657 & .84420 & $8.147 * * *$ & $c>a$ \\
\hline & b.Social Science and Management & 91 & 3.2873 & .91955 & & $d>a$ \\
\hline & c.Education & 36 & 3.6984 & .94192 & & $e>a, b$ \\
\hline & d.Natural and Life Science & 70 & 3.4531 & .83617 & & \\
\hline & e.Engineering & 50 & 3.8257 & .56799 & & \\
\hline \multirow{5}{*}{$\begin{array}{l}\text { Organizational } \\
\text { Justice }\end{array}$} & a.Humanities \& Arts & 50 & 3.3743 & .86290 & 1.355 & \\
\hline & b.Social Science and Management & 91 & 3.3077 & .95901 & & \\
\hline & c.Education & 36 & 3.5675 & .86290 & & \\
\hline & d.Natural and Life Science & 70 & 3.3694 & .82065 & & \\
\hline & e.Engineering & 50 & 3.6114 & .72788 & & \\
\hline \multirow[t]{5}{*}{ International-ization } & a.Humanities \& Arts & 50 & 3.9425 & .74711 & 1.714 & \\
\hline & b.Social Science and Management & 91 & 3.9162 & .73126 & & \\
\hline & c.Education & 36 & 4.2014 & .78676 & & \\
\hline & d.Natural and Life Science & 70 & 3.9875 & .63100 & & \\
\hline & e.Engineering & 50 & 4.1500 & .61601 & & \\
\hline \multirow{5}{*}{$\begin{array}{l}\text { Learning } \\
\text { Innovation }\end{array}$} & a.Humanities \& Arts & 50 & 3.7514 & .82688 & 1.193 & \\
\hline & b.Social Science and Management & 91 & 3.6578 & .66629 & & \\
\hline & c.Education & 36 & 3.8889 & .88137 & & \\
\hline & d.Natural and Life Science & 70 & 3.7571 & .69022 & & \\
\hline & e.Engineering & 50 & 3.8971 & .61499 & & \\
\hline \multirow{5}{*}{$\begin{array}{l}\text { Satisfaction } \\
\text { Teaching }\end{array}$} & a.Humanities \& Arts & 50 & 4.020 & .6224 & 1.906 & \\
\hline & b.Social Science and Management & 91 & 4.044 & .6130 & & \\
\hline & c.Education & 36 & 4.139 & .7617 & & \\
\hline & d.Natural and Life Science & 70 & 3.886 & .6493 & & \\
\hline & e.Engineering & 50 & 4.180 & .5226 & & \\
\hline \multirow{5}{*}{$\begin{array}{l}\text { Satisfaction } \\
\text { Research }\end{array}$} & a.Humanities \& Arts & 50 & 3.540 & .9941 & $2.916^{*}$ & $e>d$ \\
\hline & b.Social Science and Management & 91 & 3.549 & .9341 & & \\
\hline & c.Education & 36 & 3.694 & 1.0642 & & \\
\hline & d.Natural and Life Science & 70 & 3.371 & .8542 & & \\
\hline & e.Engineering & 50 & 3.920 & .6337 & & \\
\hline
\end{tabular}

Note. $* p<.05 ; * * p<.01 ; * * * p<.001$.

Table 8 summarized the results of the ANOVA analysis comparing faculty members' perceived institutional organizational climate based on their different university history. The $\mathrm{F}$ values showed no significant differences for most aspects of faculty members' perceived institutional organizational climate. The only significant mean difference was for internationalization. The post-hoc analysis showed that faculty members who worked at universities with more than 36 years of history perceived significantly higher internationalization than those at universities with fewer than 15 years of history. 
Table 8. ANOVA results of institutional organizational climate perceived by faculty members based on university history

\begin{tabular}{|c|c|c|c|c|c|c|}
\hline Aspect & University History & $\mathrm{N}$ & Mean & SD & $\mathrm{F}$ & Post-Hoc \\
\hline \multirow[t]{4}{*}{ Research Resources } & a.Less than 15 years & 101 & 3.9519 & 68699 & 2.125 & \\
\hline & b. 16 to 25 years & 61 & 4.0398 & .69161 & & \\
\hline & c. 26 to 35 years & 25 & 4.1314 & .56079 & & \\
\hline & d.Over 36 years & 110 & 4.1662 & .56335 & & \\
\hline \multirow[t]{4}{*}{ Teaching Resources } & a.Less than 15 years & 101 & 3.7376 & .79174 & .385 & \\
\hline & b. 16 to 25 years & 61 & 3.8634 & .79087 & & \\
\hline & c. 26 to 35 years & 25 & 3.8333 & 64010 & & \\
\hline & d.Over 36 years & 110 & 3.7955 & .71594 & & \\
\hline \multirow{4}{*}{$\begin{array}{l}\text { Research } \\
\text { Collaboration }\end{array}$} & a.Less than 15 years & 101 & 3.3593 & .93429 & .443 & \\
\hline & b. 16 to 25 years & 61 & 3.4543 & .89005 & & \\
\hline & c. 26 to 35 years & 25 & 3.5714 & .70349 & & \\
\hline & d.Over 36 years & 110 & 3.4026 & .86414 & & \\
\hline \multirow{4}{*}{$\begin{array}{l}\text { Organizational } \\
\text { Justice }\end{array}$} & a.Less than 15 years & 101 & 3.3380 & .91042 & .664 & \\
\hline & b. 16 to 25 years & 61 & 3.4215 & .86835 & & \\
\hline & c. 26 to 35 years & 25 & 3.5943 & .79398 & & \\
\hline & d.Over 36 years & 110 & 3.4442 & .84068 & & \\
\hline \multirow[t]{4}{*}{ International-ization } & a.Less than 15 years & 101 & 3.8713 & .77731 & $2.792 *$ & $d>a$ \\
\hline & b. 16 to 25 years & 61 & 3.9795 & 66934 & & \\
\hline & c. 26 to 35 years & 25 & 4.0700 & 69417 & & \\
\hline & d.Over 36 years & 110 & 4.1443 & 63268 & & \\
\hline \multirow{4}{*}{$\begin{array}{l}\text { Learning } \\
\text { Innovation }\end{array}$} & a.Less than 15 years & 101 & 3.6846 & .74678 & .668 & \\
\hline & b. 16 to 25 years & 61 & 3.7845 & .72074 & & \\
\hline & c. 26 to 35 years & 25 & 3.8343 & .63444 & & \\
\hline & d.Over 36 years & 110 & 3.8130 & .72243 & & \\
\hline \multirow{4}{*}{$\begin{array}{l}\text { Satisfaction } \\
\text { Teaching }\end{array}$} & a.Less than 15 years & 101 & 3.970 & .7135 & .865 & \\
\hline & b. 16 to 25 years & 61 & 4.082 & .5566 & & \\
\hline & c. 26 to 35 years & 25 & 3.960 & .5385 & & \\
\hline & d.Over 36 years & 110 & 4.091 & .6140 & & \\
\hline \multirow{4}{*}{$\begin{array}{l}\text { Satisfaction } \\
\text { Research }\end{array}$} & a.Less than 15 years & 101 & 3.505 & .9552 & .677 & \\
\hline & b. 16 to 25 years & 61 & 3.705 & .7820 & & \\
\hline & c. 26 to 35 years & 25 & 3.520 & 1.1225 & & \\
\hline & d.Over 36 years & 110 & 3.609 & .8892 & & \\
\hline
\end{tabular}

Note. $* p<.05 ; * * p<.01 ; * * * p<.001$.

Table 9 summarizes the results of the $t$-test analysis of the institutional organizational climate perceived by faculty members based on whether their institutions received the Building Teaching Excellence at University Fund award. Faculty members who worked at recipient universities perceived higher teaching resources than those at non-recipient universities. 
Table 9. T-test results of institutional organizational climate perceived by faculty at different institutional types: building teaching excellence at university fund

\begin{tabular}{|c|c|c|c|c|c|c|}
\hline Aspect & $\begin{array}{c}\text { If university has received Building } \\
\text { Teaching Excellence at University } \\
\text { Fund }\end{array}$ & $\mathrm{N}$ & Mean & SD & $\mathrm{T}$ & $\mathrm{P}$ \\
\hline \multirow[t]{2}{*}{ Research Resources } & Yes & 227 & 4.1070 & .59699 & 1.851 & .067 \\
\hline & No & 70 & 3.9265 & .74519 & & \\
\hline \multirow[t]{2}{*}{ Teaching Resources } & Yes & 227 & 3.8532 & .71452 & 2.514 & $.012 *$ \\
\hline & No & 70 & 3.5976 & .83140 & & \\
\hline \multirow[t]{2}{*}{ Research Collaboration } & Yes & 227 & 3.4594 & .84421 & 1.652 & .100 \\
\hline & No & 70 & 3.2612 & .97771 & & \\
\hline \multirow[t]{2}{*}{ Organizational Justice } & Yes & 227 & 3.4651 & .82543 & 1.616 & .109 \\
\hline & No & 70 & 3.2571 & .97426 & & \\
\hline \multirow[t]{2}{*}{ Internationalization } & Yes & 227 & 4.0424 & .67165 & 1.254 & .213 \\
\hline & No & 70 & 3.9170 & .79575 & & \\
\hline \multirow[t]{2}{*}{ Learning Innovation } & Yes & 227 & 3.8037 & .67310 & 1.653 & .099 \\
\hline & No & 70 & 3.6408 & .85740 & & \\
\hline \multirow[t]{2}{*}{ Satisfaction with Teaching } & Yes & 227 & 4.035 & .6370 & -.088 & .930 \\
\hline & No & 70 & 4.043 & .6241 & & \\
\hline \multirow[t]{2}{*}{ Satisfaction with Research } & Yes & 227 & 3.577 & .8810 & -.298 & .766 \\
\hline & No & 70 & 3.614 & 1.0114 & & \\
\hline
\end{tabular}

Note. ${ }^{*} p<.05 ; * * p<.01 ; * * * p<.001$.

Table 10 summarizes the results of the $t$-test analysis of the institutional organizational climate perceived by faculty members based on whether their institutions received the Building World-Class University Fund. Faculty members who worked at recipient universities perceived significantly higher research resources, research collaboration, internationalization, learning innovation, and research satisfaction than those at non-recipient universities.

Table 10. T-test results of institutional organizational climate perceived by faculty members at different institutional types: building world-class university fund

\begin{tabular}{|c|c|c|c|c|c|c|}
\hline Aspect & $\begin{array}{l}\text { If university has received Building } \\
\text { World-Class University Fund }\end{array}$ & $\mathrm{N}$ & Mean & SD & $\mathrm{T}$ & $\mathrm{P}$ \\
\hline Research & Yes & 123 & 4.2044 & .58562 & 3.227 & $0.001 * *$ \\
\hline Resources & No & 174 & 3.9655 & .65689 & & \\
\hline Teaching & Yes & 123 & 3.7276 & .75273 & -1.262 & 0.208 \\
\hline Resources & No & 174 & 3.8391 & .74706 & & \\
\hline \multirow[t]{2}{*}{ Research Collaboration } & Yes & 123 & 3.5610 & .81639 & 2.463 & $0.014^{*}$ \\
\hline & No & 174 & 3.3079 & .90981 & & \\
\hline \multirow[t]{2}{*}{ Organizational Justice } & Yes & 123 & 3.4843 & .84805 & 1.143 & 0.254 \\
\hline & No & 174 & 3.3678 & .87704 & & \\
\hline \multirow[t]{2}{*}{ Internationalization } & Yes & 123 & 4.2043 & .59718 & 4.228 & $0.000 * * *$ \\
\hline & No & 174 & 3.8750 & .74201 & & \\
\hline \multirow[t]{2}{*}{ Learning Innovation } & Yes & 123 & 3.8711 & .68498 & 2.135 & $0.034^{*}$ \\
\hline & No & 174 & 3.6905 & .74081 & & \\
\hline
\end{tabular}




\begin{tabular}{lllllll}
\hline Satisfaction with Teaching & Yes & 123 & 4.098 & .5925 & 1.388 & .166 \\
& No & 174 & 3.994 & .6584 & & \\
Satisfaction with Research & Yes & 123 & 3.748 & .8356 & 2.658 & $.008^{* *}$ \\
& No & 174 & 3.471 & .9476 & & \\
\hline
\end{tabular}

Note. $* p<.05 ; * * p<.01 ; * * * p<.001$.

Table 11 summarizes the results of the stepwise regression of predicting the dependent variable of teaching performance satisfaction. Three regression results are displayed in this table. The author entered all institutional organizational climate variables perceived by all samples into the regression model to predict their teaching performance satisfaction. In the first model, all samples were included, and research resources were the significant predictor of their teaching performance satisfaction. The second model analyzed data from samples working at universities that received Building Teaching Excellence at University Fund, and research resources were the significant predictor. For samples working at universities that received Building World-Class University Fund, internationalization was the significant predictor in the model predicting faculty members' teaching performance satisfaction.

Table 11. Stepwise regression results predicting "my satisfaction with teaching performance in the last five years"

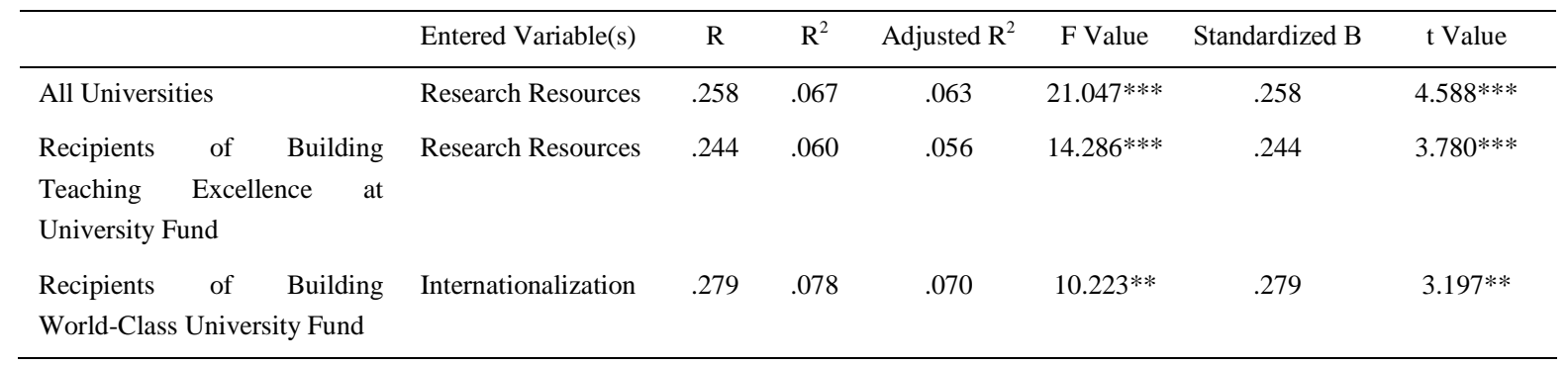

Note. $* p<.05 ; * * p<.01 ; * * * p<.001$.

Table 12 summarizes the results of the stepwise regression for predicting research performance satisfaction. Three regression results are displayed in this table. The author entered all institutional organizational climate aspects into the regression model to predict their research performance satisfaction. In the first model, all samples were included, and organizational justice aspect was the significant predictor of their research performance satisfaction. The second model included samples working at universities that received Building Teaching Excellence at University Fund; research collaboration was the significant predictor of research performance satisfaction. For samples working at universities that received the Building World-Class University Fund, internationalization was the significant predictor predicting faculty members' research performance satisfaction.

Table 12. Stepwise regression results predicting "my satisfaction with research performance in the last five years"

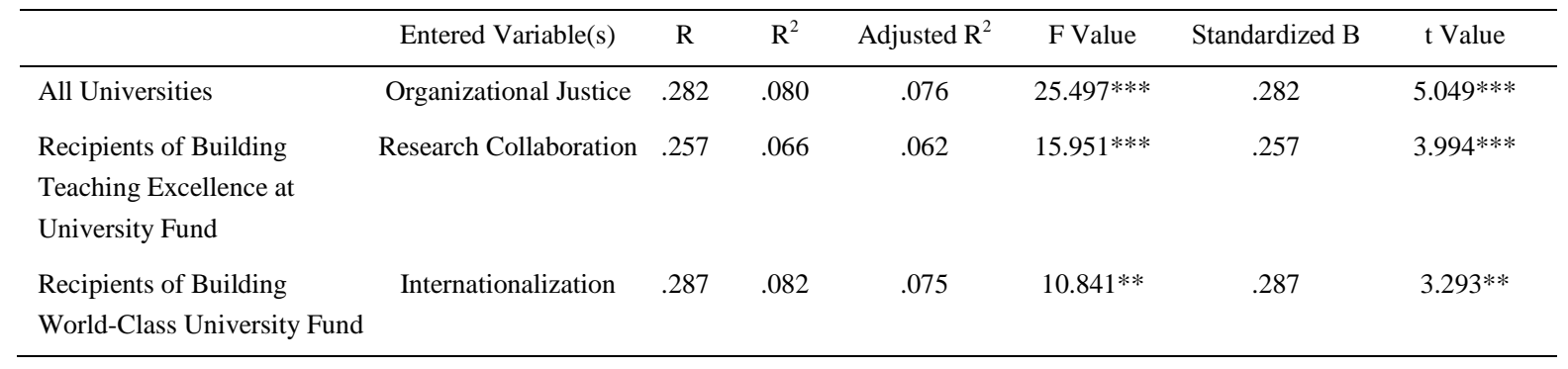

Note. $* p<.05 ; * * p<.01 ; * * * p<.001$. 


\section{Conclusion}

Organizational climate is an important indicator of an organization's positive development. In the past, higher education institutions in Taiwan have been highly regulated by the central government and have had less autonomy for changing their internal organizational structures; thus, organizational climate has not been an important issue. However, when globalization strongly influenced higher education in Asia, the Asian countries tried to offer more autonomy to universities; consequently, universities moved toward scientific management and emphasized organizational performance and efficiency. Taiwan is no exception to this trend. The Taiwanese government implemented several competition-based funding programs to encourage higher education institutions to become self-regulated and more competitive in the global higher education field. The relevant policies for pursuing teaching excellence and research outcomes are part of this reform. Thus, studying the institutional organizational climate in higher education is critical for current higher education changes in Taiwan, and it is even more important to study organizational climate's effects on universities.

This research developed a questionnaire to explore Taiwanese university faculty members' perceived institutional organizational climate and their satisfaction with teaching and research in the last five years. This research found that Taiwanese faculty members generally perceived a positive institutional organizational climate in all aspects as well as a relatively higher level of research resources and internationalization but relatively lower levels of research collaboration and organizational justice. Taiwanese faculty members perceive higher satisfaction with their teaching performance in the last five years but lower satisfaction with their research performance. Male faculty members in Taiwan perceive significantly higher climate aspects of research resources, research collaboration, organizational justice, and teaching and research satisfaction. Taiwanese faculty members at national universities tend to perceive a higher level of teaching resources and research satisfaction. Newly hired and veteran faculty members tend to perceive more research resources, while those in their mid-level career tend to perceive fewer research resources. Taiwanese faculty members in humanities and arts tend to perceive less research collaboration than those in education, natural and life sciences, and engineering. Taiwanese faculty members at universities with a longer history tend to perceive a greater climate of internationalization. In terms of policy effects on institutional organizational climate in Taiwan, faculty members at recipients of the Building Teaching Excellence at University Fund tend to perceive more teaching resources. Meanwhile, faculty members at recipients of the Building World-Class University Fund tend to perceive more research resources, research collaboration, internationalization, learning innovation, and research satisfaction.

The findings of this research implicate that gender difference is an important factor to consider when university administration wants to enhance the internal organizational climate in Taiwan. Female faculty members perceived less research resources, research collaboration, organizational justice, and teaching and research satisfaction. This finding suggests that Taiwan's government and higher education institutions can start with balancing the gender difference in these climate factors through encouragement or actual intervention. Years of employment, university history, and research field all have different effects on faculty members' perceived organizational climate aspects. Universities that received the Building World-Class University Fund tend to perform better on numerous aspects in the organizational climate, indicating that these universities are better-performing organizations in Taiwan regardless of the policy effects or that they were already excellent universities before the fund and after the fund became excellent institutions. Thus, the Taiwanese government can consider the next step of policy intervention to equally enhance organizational climate of all universities or to strengthen a few institutions to make them top universities in the world's rankings.

\section{References}

Astin, A. W. (1968). The college environment. Washington, D. C.: American Council on Education.

Bronstein, P., \& Farnsworth, L. (1998). Gender differences in faculty experiences of interpersonal climate and processes for advancement. Research in Higher Education, 39(5), 557-585. http://dx.doi.org/10.1023/A:1018701722855

Deem, R., Mok, K. H., \& Lucas, L. (2008). Transforming higher education in whose image? Exploring the concept of the "world-class" university in Europe and Asia. Higher Education Policy, 21, 83-97. http://dx.doi.org/10.1057/palgrave.hep.8300179

Educational Testing Service. (1973). Institutional goals inventory. Princeton, N. J.

Field, G. R., \& Abelson, M. A. (1982). Climate: A reconceptualization and proposed model. Human Relations, 35(3), 181-201. http://dx.doi.org/10.1177/001872678203500302 
Litwin, G. H., \& Stringer, R. (1966). The influence of organizational climate. Boston: Harvard University Press.

Marginson, S. (2006). Dynamics of national and global competition in higher education. Higher Education, 52(1), 1-39. http://dx.doi.org/10.1007/s10734-004-7649-x

Ministry of Education in Taiwan. (2015). Statistics of higher education institutions in Taiwan. Retrieved from http://www.edu.tw/pages/detail.aspx?Node=4076\&Page=20047\&Index $=5 \& W I D=31 \mathrm{~d} 75 \mathrm{a} 44-$ efff-4c44-a075 $-15 \mathrm{a} 9 \mathrm{eb} 7 \mathrm{aecdf}$

Moran, E. T., \& Volkwein, J. F. (1988). Examining organizational climate in institutions of higher education. Research in Higher Education, 28(4), 367-383. http://dx.doi.org/10.1007/BF01006405

Neumann, Y. (1978). Predicting faculty job satisfaction in university departments. Research in Higher Education, 9, 261-275. http://dx.doi.org/10.1007/BF00976999

Owens, R. E., \& Valesky, T. C. (2014). Organizational behavior in education: Leadership and school reform. Pearson Publisher.

Peterson, M. W., \& White, T. H. (1992). Faculty and administrator perceptions of their environments: Different views or different models of organization? Research in Higher Education, 33(2), 177-204. http://dx.doi.org/10.1007/BF00973578

Peterson, M. W., Cameron, K. S., Jones, P., Mets, L. A., \& Ettington, D. (1986). The organizational context for teaching and learning: A review of the research literature. Ann Arbor, MI, National Center for Research to Improve Postsecondary Teaching and Learning.

Shin, J. C., \& Harman, G. (2009). New challenges for higher education: Global and Asia-Pacific perspectives. Asia Pacific Education Review, 10(1), 1-13. http://dx.doi.org/10.1007/s12564-009-9011-6

Trow, M. (1972). The expansion and transformation of higher education. International Review of Education, 18(1), 61-84. http://dx.doi.org/10.1007/BF01450272

\section{Copyrights}

Copyright for this article is retained by the author(s), with first publication rights granted to the journal.

This is an open-access article distributed under the terms and conditions of the Creative Commons Attribution license (http://creativecommons.org/licenses/by/3.0/). 